\title{
Correlation between Building Damages and Losses with the Microzonation Map of Mataram-Case Study: Lombok Earthquake 2018, Indonesia
}

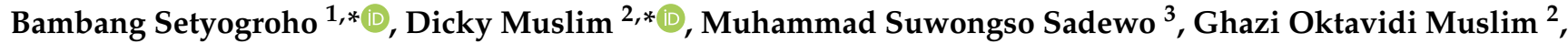 \\ Safri Burhanuddin ${ }^{4}$ and Hendarmawan Hendarmawan 1 ,* \\ 1 School of Postgraduate, University of Padjadjaran, Bandung 40132, Indonesia \\ 2 Faculty of Geological Engineering, University of Padjadjaran, Bandung 40132, Indonesia; \\ ghazi17001@mail.unpad.ac.id \\ 3 Research Fellow of Geological Engineering, Faculty of Earth Sciences and Technology, \\ Bandung Institute of Technology, Bandung 40116, Indonesia; dewongs.geo07@gmail.com \\ 4 Coordinating Ministry of Maritime and Investment, Jakarta 10340, Indonesia; safribur@gmail.com \\ * Correspondence: bambang17003@mail.unpad.ac.id (B.S.); d.muslim@unpad.ac.id (D.M.); \\ hendarmawan@unpad.ac.id (H.H.)
}

check for updates

Citation: Setyogroho, B.; Muslim, D.; Sadewo, M.S.; Muslim, G.O.;

Burhanuddin, S.; Hendarmawan, H.

Correlation between Building

Damages and Losses with the

Microzonation Map of

Mataram-Case Study: Lombok

Earthquake 2018, Indonesia.

Sustainability 2022, 14, 2028.

https://doi.org/10.3390/ su14042028

Academic Editors: Stefano Morelli, Veronica Pazzi and Mirko Francioni

Received: 20 January 2022

Accepted: 7 February 2022

Published: 10 February 2022

Publisher's Note: MDPI stays neutral with regard to jurisdictional claims in published maps and institutional affiliations.

Copyright: () 2022 by the authors. Licensee MDPI, Basel, Switzerland. This article is an open access article distributed under the terms and conditions of the Creative Commons Attribution (CC BY) license (https:// creativecommons.org/licenses/by/ $4.0 /)$.

\begin{abstract}
The high intensity of the earthquake on Lombok Island on 5 August 2018, with a magnitude of $7.0 \mathrm{Mb}$, caused material losses experienced by the affected residential areas. The Indonesian Geological Agency in 2015 published a microzonation map that mapped zones prone to earthquake shocks to mitigate disasters. This study aimed to compare the level of damage and loss in residential areas due to earthquakes in Mataram City with earthquake-prone zones using a microzonation map. The correlation between damage and loss value of residentials with microzonation maps was evaluated using the overlay method. The results showed that the level of damage and the value of the loss of houses in the high disaster-prone zone (red zone) showed the highest loss value. In comparison, the level of losses in the moderate disaster-prone zone (yellow zone) and light disasterprone zone (blue zone) on the microzonation map shows a low and lower loss value. This study concludes that the microzonation map helps determine the damage zone and the level of disaster vulnerability caused by the earthquake hazard.
\end{abstract}

Keywords: microzonation; earthquake; level of damage and loss; disaster vulnerability

\section{Introduction}

The location of Indonesia in the collision zone causes frequent natural disasters. Earthquakes are one of such disasters caused by tectonic activities. The dynamic interaction of numerous tectonic plates in eastern Indonesia causes high seismicity rates, which resulted in catastrophic damaging earthquake sequences on Lombok Island in 2018 [1-3]. Based on the National Disaster Management Agency (BNPB) records, from the beginning of 2017 to June 2018, there have been 4006 disasters in Indonesia, with 30 tectonic earthquakes on Lombok Island occurring in August 2018 with a magnitude of 5.9-6.9. The earthquake in Lombok claimed at least 481 lives and caused an economic loss of US\$ 514,000,000 as of 17 August 2018 [4]. These financial losses are caused mainly by damage to infrastructure and buildings.

Natural disasters are a significant concern in Mataram City. A natural disaster is an unanticipated event or set of circumstances that endanger and disrupts people's lives and livelihoods as a result of natural causes, both by natural factors and/or non-natural factors and human factors, resulting in fatalities, environmental damages, property losses, and psychological impacts [5]. Examples of natural catastrophes include floods, tsunamis, earthquakes, and landslides [6,7]. After the earthquake disaster in Lombok in August 2018, the damage level of the Municipality of Mataram ranked fourth out of six regencies 
in Lombok with a total loss of US\$ 69,008,289. The tremendous damage and loss to the settlement sector reached a value of US\$34,907,209, damage to the housing subsector reached US\$32,500,610, and other losses, including cleaning of debris, worth US\$ $1,600,470[4]$.

Earthquakes are the vibrations or shocks that occur on the surface of the Earth caused by the collisions between the tectonic plates, active fault zones, volcanic eruption activity, and rock debris. Lombok Island is located north of the subduction zone, where the Indo/Australian Plate collides and subducts below the Eurasian Plate with a convergence rate of $44-68 \mathrm{~mm} / \mathrm{yr}$ [8].

It is crucial to distinguish between risk and vulnerability. Seismic risk is the risk of damage and consequential loss to a particular structure or collection of structures over a specific period. The anticipated losses from all degrees of hazard severity are included in risk, taking their occurrence probability into account, whereas the vulnerability of an element is generally specified for a specific hazard severity level. Seismic vulnerability analysis in urban environments focuses mainly on building structural, geological, and geographical information directly related to potential human and economic losses in the case of a seismic episode [9]. On the other side, Lombok Island is locked between two active faults, the Flores back arc thrust on the north with a convergence rate of ca. $9.9 \mathrm{~mm} / \mathrm{yr}$ and the normal fault of Sumbawa with a rate of $0.5 \mathrm{~mm} / \mathrm{yr}$ [10]. Those faults influenced the earthquake events in Lombok Island (Figure 1).

The earthquake with the greatest strength occurred on 19 August 2018, with a magnitude of $6.9 \mathrm{Mb}$, and the epicenter at a radius of $30 \mathrm{~km} \mathrm{NE}$ of East Lombok. At the same time, five other earthquakes occurred with a magnitude of $4.9 \mathrm{Mb}-5.7 \mathrm{Mb}$, whose shaking intensities were scattered in several areas in the island of Lombok, with the distribution shown in Figure 2. The earthquake on the island of Lombok, taking place in July-August 2018, had negative impacts, such as fatalities, damages, and material losses. From January through October 2018, there were 98 earthquakes with a magnitude ranging from $4.1 \mathrm{Mb}-6.9 \mathrm{Mb}$. The depth of the earthquake sources was between $5.7 \mathrm{~km}-121.9 \mathrm{~km}$ [11]; the earthquakes that occurred were dominated in the NW-NE region of the island of Lombok.

The microzonation map of Mataram City from the Geological Agency (2015) is used as an estimated vulnerability zoning model. The map is used as a basis to prepare a zonation map by using the microtremor. Bertelli and Omori were the first to discover microtremors in 1909 , while Guttenberg was the first to introduce engineering uses of microtremors [12,13]. Microtremor measurements are valuable for assessing seismic threats in the near-surface substructure [14,15]. Microtremor (or ambient vibration) methods analyze the mechanical qualities of the Earth's subsurface, particularly seismic velocities, by measuring background seismic noise. Seismic noise is the constant vibration of the Earth's surface caused by a combination of the low-frequency (less than $1 \mathrm{~Hz}$ ) natural phenomena (earthquakes, wind, tides, rivers, rain, variations in atmospheric pressure) and high-frequency (greater than $1 \mathrm{~Hz}$ ) human activities [16,17]. Idriss and Boulanger [18] showed that damage to building structures due to earthquake intensity of ground shocks during an earthquake was significantly influenced by local geological and soil conditions. The microzonation divides or classifies areas of zones that have relatively similar potential shocks and disasters. Their engineering characteristics have local effects. Hard rock sites will experience a low shock intensity, while soft soil will experience a high shock intensity [19-22].

The purpose of this research was to determine the accuracy of the microzonation map against actual building losses and damage when the Lombok earthquake in 2018 occurred. The high accuracy of microzonation maps is perfect for development plans such as urban planning and financial risk transfer strategies. The burden of the state budget will be reduced in the future if disaster impact mitigation using the prediction of microzonation maps goes well; in turn, it will also reduce casualties and material losses. 


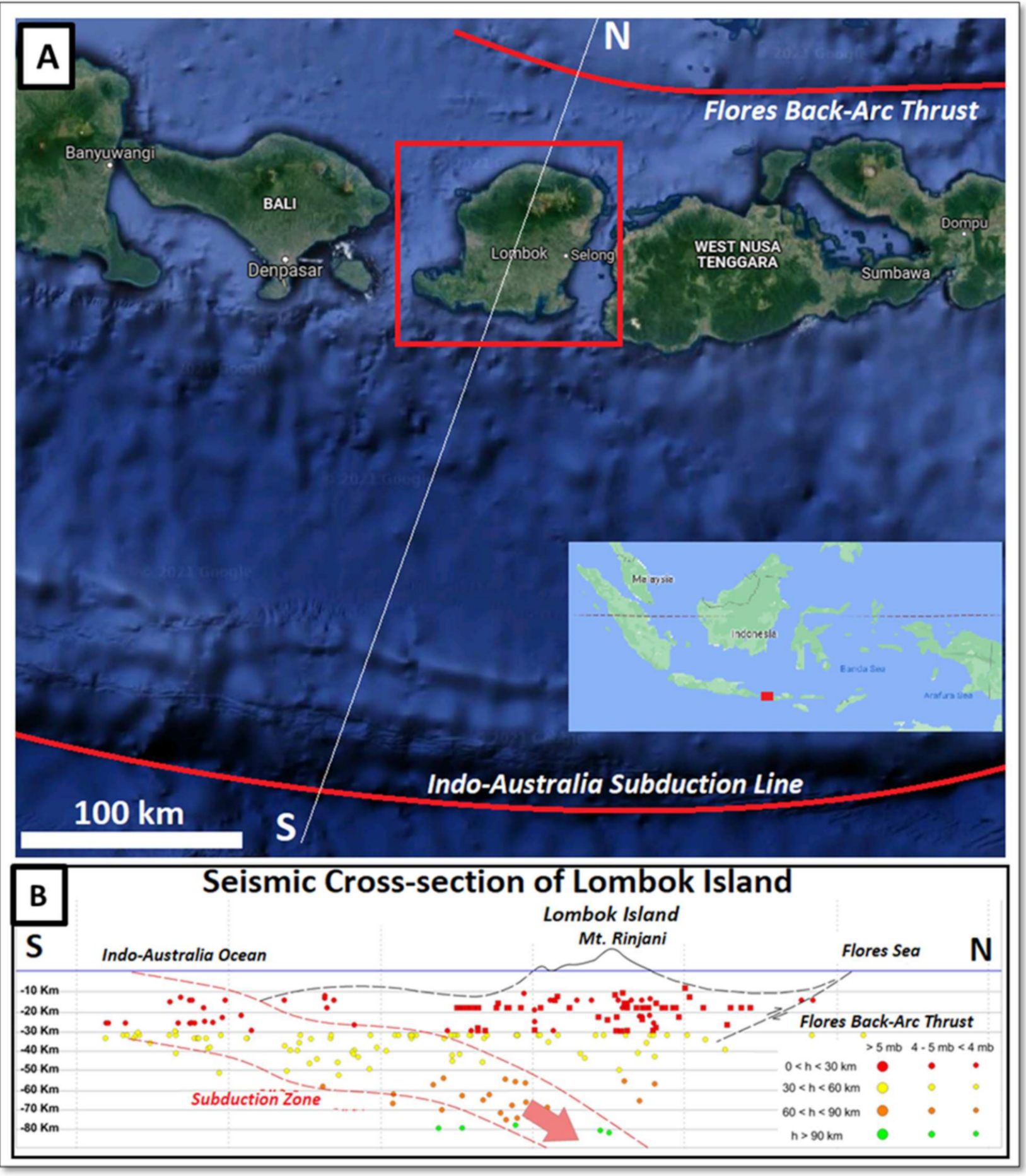

Figure 1. (A) Map view of Lombok Island (Google Maps). (B) Cross-section of Lombok Island [10]. 


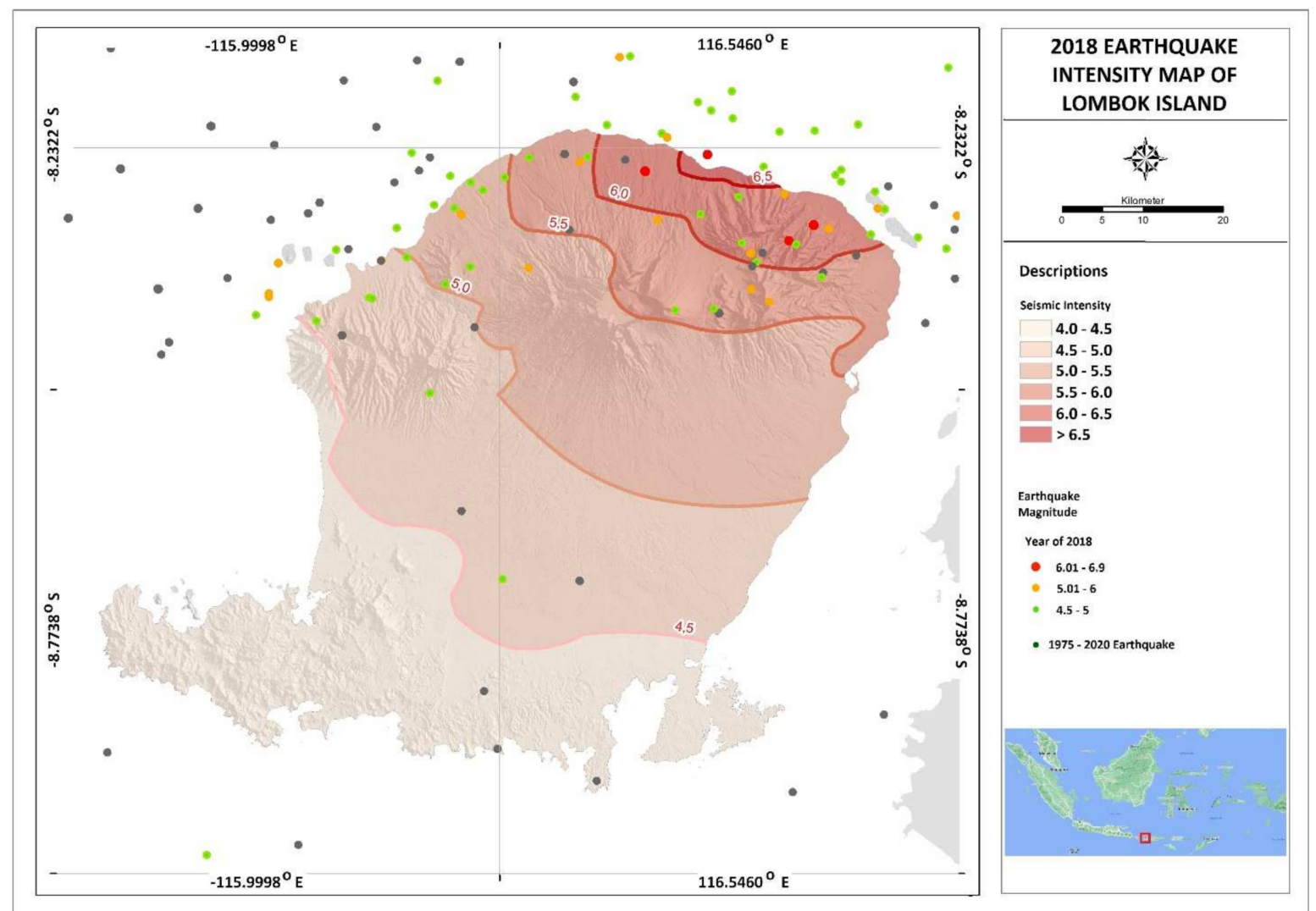

Figure 2. Distribution and intensity map of the Lombok Island Earthquakes, January-October 2018 (Epicenter coordinate based on USGS).

\section{Materials and Methods}

The availability of microzonation maps is one of the factors that makes Mataram City a research area, with well-collected data on losses and damages to buildings after the 2018 Lombok earthquake. The city of Mataram has six districts, such as the Ampenan District, Sekarbela District, Selaparang District, Mataram District, Cakranegara District, and Sandubaya District. All districts have different values of loss and deterioration to the buildings and their microzonation areas.

\subsection{Study Area}

Mataram is a land relatively flat, undulating topography, with a slope of $0-2 \%$ covering an area of 3.216 hectares and a bumpy area with a slope of more than $2-14 \%$ surrounding an area of 2.909 hectares. The altitude of Mataram City is approximately $0-50 \mathrm{~m}$ above sea level. These conditions indicate that most of the city is a plain area. The western part of the city is occupied by the flat-sloping area while the eastern has rather high-bumpy relief. The overlay area, with flat physiography, has two conflicting implications. First, flat areas have positive values, namely the construction of infrastructure and facilities which physically have fewer technical obstacles, and the development funding is relatively cheaper. Second, a flat area with an altitude almost parallel to the sea level has terrible implications, including flood-prone areas.

Based on the Geological map of Lombok sheet West Nusa Tenggara [23], three rock formations are covering the research area: Kalikupang Formation (Tqp), Kalibabak Formation (Tqb), and Lekopiko Formation (Qvl) that consists of volcanic rocks, sedimentary rocks, and intrusive rocks whose ages range from Tertiary to Quaternary. The engineering geological map of the Lombok Island, Mataram, lays on the geological unit of the Alluvium deposit (Al), consisting of the river, coastal, and swamp deposits, composed of silty sand, sandy silt, and loose sand [24]. Sedimentary swamp comprises sandy silt, silty clay, black to 
grey color, fine-medium grained, very soft-firm, medium to high porosity. River sediment consists of sandy silt to silty clay and loose sand, brownish yellow-brown. It contains gravel, fine-medium-grained, very soft-dense, low to moderate plasticity, $3.50-6.50 \mathrm{~m}$ thick. Coastal deposits are black to grey sand, fine-grained, high porosity, containing shells. The engineering geological constraints or geological disasters prone are floods, abrasions, and tsunamis.

\subsection{Damage and Loss Due to the Mataram Earthquake in August 2018}

The earthquakes hit Mataram City, impacting six districts, including Ampenan, Sekarbela, Selaparang, Mataram, Cakranegara, and Sandubaya. The first earthquake occurred on 5 August 2018, with a magnitude of $7 \mathrm{Mb}$ at $19.46 \mathrm{CIT}$ (Central Indonesian Time). The coordinates of the epicenter of the earthquakes are $8.37^{\circ} \mathrm{S}, 116.48^{\circ} \mathrm{E}$, about $27 \mathrm{~km}$ NE. The depth of the quake is around $15 \mathrm{~km}$. The aftershock that caused considerable damage in Mataram was on August 9, 2018, at 13.25 CIT, with a magnitude $6.2 \mathrm{Mb}$ located at $8.36^{\circ} \mathrm{S}-116.22^{\circ} \mathrm{E}, 27 \mathrm{~km}$ NE of Mataram with a depth of $12 \mathrm{~km}$. On 19 August 2018, the next earthquake occurred at $22.56 \mathrm{CIT}$, located $75 \mathrm{~km}$ NE of Mataram with the magnitude V-VI of MMI (Modified Mercalli Intensity) [4].

The impacts of the Lombok earthquakes caused damages and losses in various sectors such as residential, infrastructure, social, economic, and cross-sectoral, which have disrupted public activities and services in the affected areas based on the data from the Post-Natural Disaster Reconstruction and Rehabilitation Action Plan. This natural disaster caused total damage and loss of 69,008,289 US\$. The tremendous damage and loss occurred in some sectors comprising the residential sector amounted to 34,905,750 US\$; the social sector amounted to 25,335,416 US\$; the cross-sector amounted to 7,023,475 US\$; the productive economic industries amounted to 1,743,648 US\$.

The amount or pattern of building damage caused by the earthquake that impacted Mataram demonstrates the pattern's conformance with the microzonation map. The proportion of building damage by the district is depicted in Figure 3. The Sekarbela district (21.66 percent) and Ampenan (19.76 percent) have suffered the worst damage, while the Mataram district (8.75 percent), Selaparang (8.75 percent), and Sandubaya (7.76 percent) have sustained minor damage. The Cakranegara district in the blue zone is the least affected (1.7 percent).

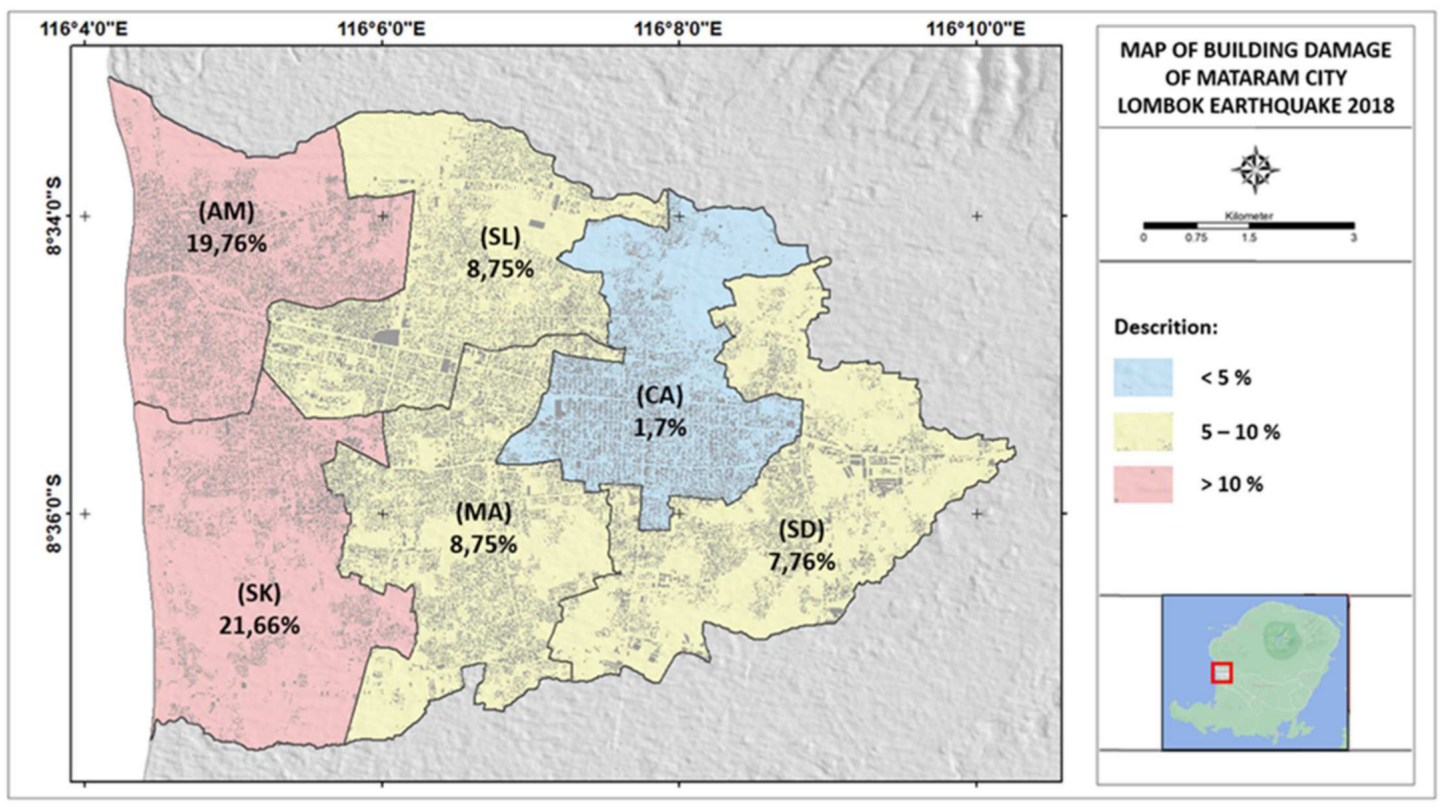

Figure 3. Buildings Damaged Map by the 2018 Lombok Earthquake in Mataram City. 


\subsection{Microzonation Map}

The Potential Earthquake Ground Shaking Hazard Map (Microzonation) Mataram City, West Nusa Tenggara Province, produces three types of zones, namely red, yellow and blue zones (Figure 4). The red zone indicates that the area has a relatively high level of shaking with the morphology of volcanic fluvial plains. The yellow zone means that the area has a fairly medium level of shock in volcanic fluvial plains. The blue one indicates that the area has a relatively low level of shock with the morphology of the undulating volcanic plain of volcanoes. Regional zones on the Microzonation Map of Mataram involve four seismic microzonation parameters, which are dominant periods, soft sediment thickness, average rock/soil amplification, and soil rock site classification.

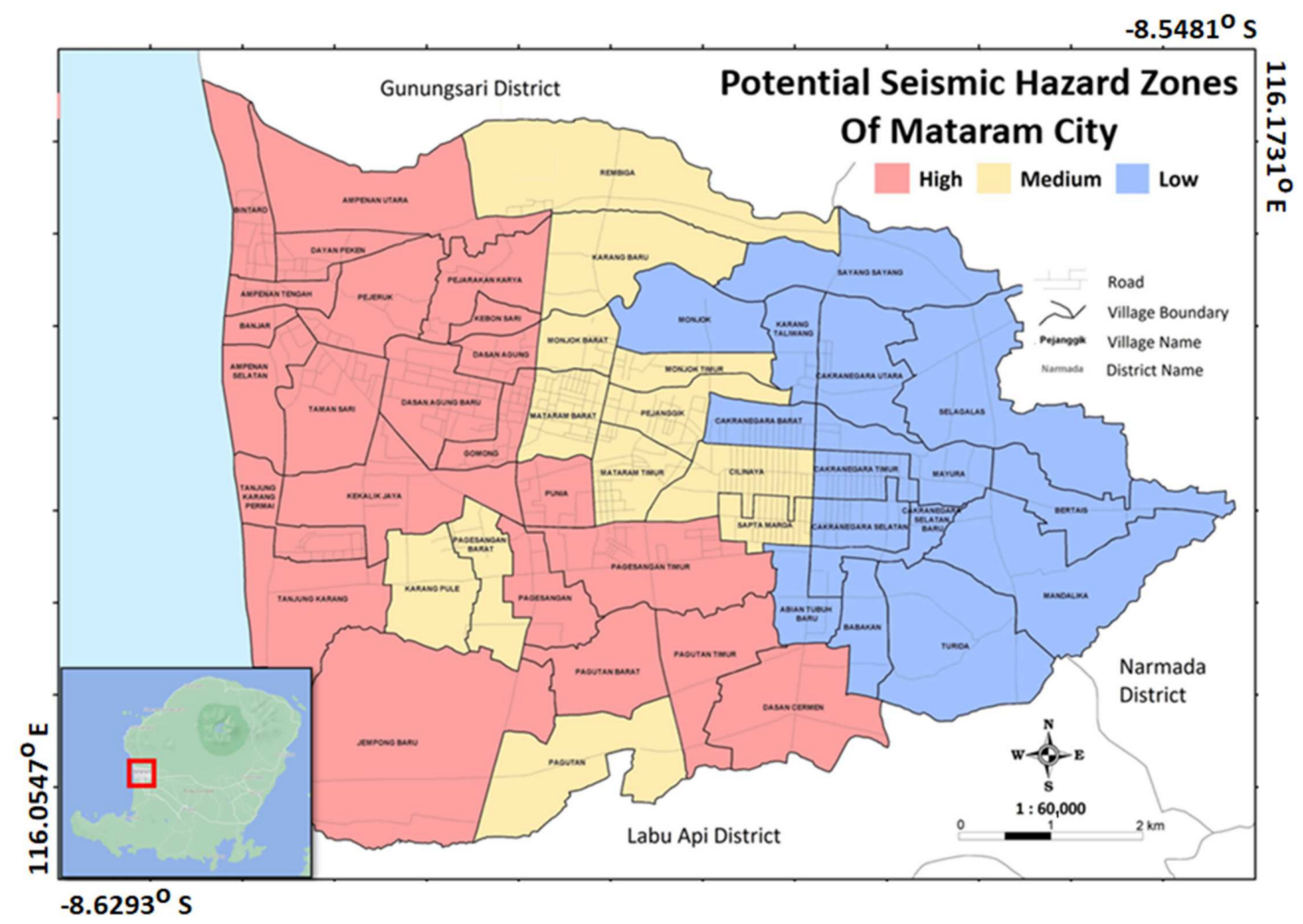

Figure 4. Microzonation Map of Mataram City (Modified from Geological Agency).

The red zone has the characteristics of a dominant period of more than $0.5 \mathrm{~s}$, a soft sediment thickness of more than $30 \mathrm{~m}$, an average amplification ranging from 1.9 to 2.3, and a site class of soft to medium soil. While the yellow zone has the characteristics of a dominant period ranging from 0.25 to $0.5 \mathrm{~s}$, a thickness of soft sediment ranging from 10 to $30 \mathrm{~m}$, an average amplification ranging from 1.6 to 1.9 , and a medium soil site class. Finally, the blue zone has the characteristics of a dominant period of less than $0.25 \mathrm{~s}$, a thickness of soft sediment below $10 \mathrm{~m}$ and amplification below 1.6, and a hard soil site class.

After generating three types of zones based on the level of shock on the Earthquake Potential Map (Microzonation) of Mataram City, West Nusa Tenggara Province, these zones can be developed based on disaster mitigation recommendations for safer development.

The red zone has a relatively high level of shock. Therefore, this area is not recommended to construct houses or critical and emergency (IV) facilities. However, once facility (IV) has been built, it needs to be reviewed with special geological studies, site investigations, and specialized foundation designs. The yellow zone with a relatively moderate level of shock is recommended for medium-risk (II) facilities built in this zone. The construction 
of medium-risk (II) facilities must comply with the provisions of the local building code. The blue zone, which has a relatively low level of shock, is recommended to build facilities in building categories I, II, III, and IV (Table 1).

Table 1. Matrix of potential earthquake hazard of Mataram City (Modified from Geological Agency, 2015).

\begin{tabular}{|c|c|c|c|}
\hline $\begin{array}{c}\text { Potential Seismic } \\
\text { Hazard Zone }\end{array}$ & Landform & Land Use & Recommendations \\
\hline $\begin{array}{c}\text { High Potential Seismic } \\
\text { Hazard Zone }\end{array}$ & Fluvio Volcanic Plan & $\begin{array}{l}\text { Public services } 70 \% \text {, } \\
\text { Settlement } 50 \% \\
\text { Plantation } 60 \% \text {, } \\
\text { Industrial area } 100 \% \\
\text { Defense and security } 50 \% \text {, } \\
\text { Agricultural area } 60 \%\end{array}$ & $\begin{array}{l}\text { Essential and emergency facilities } \\
\text { (IV) should not be built in this zone. } \\
\text { Existent facilities (IV) should be } \\
\text { re-evaluated. Retro-fitting of facilities } \\
\text { (IV) should be performed. } \\
\text { - Require special geological studies, } \\
\text { site investigations and special } \\
\text { foundation designs. } \\
\text { Low-risk facilities (I) can be built in } \\
\text { this zone. }\end{array}$ \\
\hline $\begin{array}{l}\text { Medium Potential } \\
\text { Seismic Hazard Zone }\end{array}$ & Fluvio Volcanic Plain & $\begin{array}{l}\text { Public services } 15 \% \text {, } \\
\text { Settlement } 30 \% \text {, } \\
\text { Plantation } 25 \% \text {, } \\
\text { Defense and security } 30 \% \text {, } \\
\text { Agricultural area } 20 \%\end{array}$ & $\begin{array}{l}\text { - Medium-risk facilities (I, II) can be } \\
\text { built in this zone. } \\
\text { Enact and adopt building code } \\
\text { regulations that adequately represent } \\
\text { the seismic hazards. (I, II) }\end{array}$ \\
\hline $\begin{array}{c}\text { Low Potential Seismic } \\
\text { Hazard Zone }\end{array}$ & $\begin{array}{l}\text { Undulating Fluvio } \\
\text { Volcanic Plain }\end{array}$ & $\begin{array}{l}\text { Public services } 15 \% \text {, } \\
\text { Settlement } 20 \% \\
\text { Plantation } 15 \% \text {, } \\
\text { Defense and security } 20 \% \text {, } \\
\text { Agricultural area } 20 \%\end{array}$ & $\begin{array}{l}\text { - Facilities (I, II, III and IV) can be built } \\
\text { in this zone. } \\
\text { - City development is recommended in } \\
\text { this zone. }\end{array}$ \\
\hline
\end{tabular}

Note: (Facilities I: low risk, such as agriculture, livestock, warehouse, fishery; Facilities II: Medium Risk, such as housing, apartment, office buildings, markets, factories; Facilities III: High Risk, such as stadium, cinemas, medical facilities, prisons; Facilities IV: Essential Facilities, such as hospitals, monumental buildings, schools, energy generation center, public facilities for emergencies.)

According to the microzonation map, it has been found that each district has a zonation of the potential hazardous ground shocks that differ according to the distribution of soil and rocks characteristics. The largest red zone coverages are respectively in Sekarbela (SK), Ampenan (AM), Mataram MA), Selaparang (SL), Sandubaya (SD) and Cakranegara (CA). The results of microzonation research are directly proportional to the damage and losses that occur. These facts are summarized in Table 1, where it has been found that the Sekarbela (SK) district, with the most significant red zone of $88.52 \%$, experienced enormous damage and loss. Meanwhile, the Cakranegara (CA) district, which has the largest blue zone of $85.37 \%$, experienced the slightest damage and loss.

\subsection{Worksteps}

The Geographic information system is a computer-based information system that focuses on the geography of an area, which can be used and designed to compile, manipulate, process, display, and analyze data that have spatial information. The relation between equal intervals, natural breaks, manual and statistical examination, all of which are GIS-default operations, are the most common mathematical approaches for data classification [25].

The GIS-based data for the land-use suitability analysis has been used in various situations, including geological favorability [26-28]. Simple processes, such as laying a road map over a map of local wetlands, or more complex processes, such as multiplying and adding map characteristics of different values to calculate averages and correlations, can be represented by these outputs. This process could be a visual action at its most basic level, but analytical activities require combining one or more data layers [29-32].

The superimposed research was conducted by correlating the Earthquake Hazard Potential (Microzonation) map of Mataram City, West Nusa Tenggara Province, with data on 
damage and losses in each district in Mataram Municipality, based on the BNPB report [4]. The comparison of the two data aimed to determine the correlation between both data is either directly or inversely proportional, or even irregular way. The comparisons were also made on the residential area data from each district obtained from the digitization results of Google Earth satellite imagery. It was performed because the variable density of residential could affect the value of losses caused by earthquake disasters.

This research uses the weighted overlay GIS method (Figure 5). The weighted overlay method analyses spatial data using the overlay technique of several raster maps related to the factors that affect the vulnerability assessment of a problem. Weighted Overlay can combine various inputs in a grid map [33]. This method solves problems with many criteria, such as optimal site selection or suitability modeling.
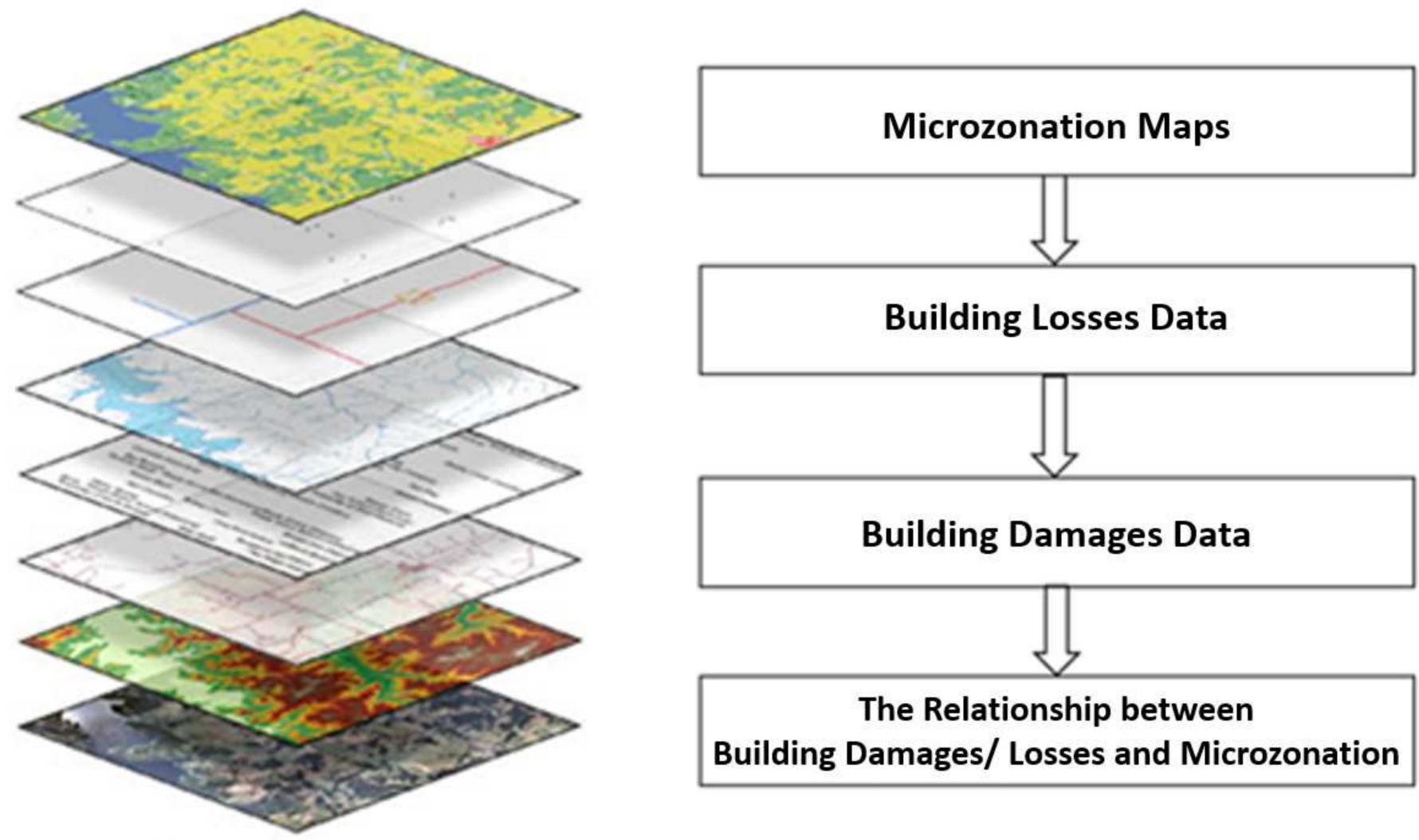

Figure 5. Illustration of overlay method in this research.

Applying the latter approach to the case of the loss and damage data values and the microzonation map units above (Figure 6), the average element values can be obtained using Equation (1) [26]:

$$
Z i=\frac{\sum_{j=1}^{n} \partial i j . z j}{\sum_{j=1}^{n} \partial i j}
$$

where are:

$i=$ microzonation units

$j=$ loss damage data values

$z=$ variable in the source zones

$\partial i j=$ overlapping target zone 


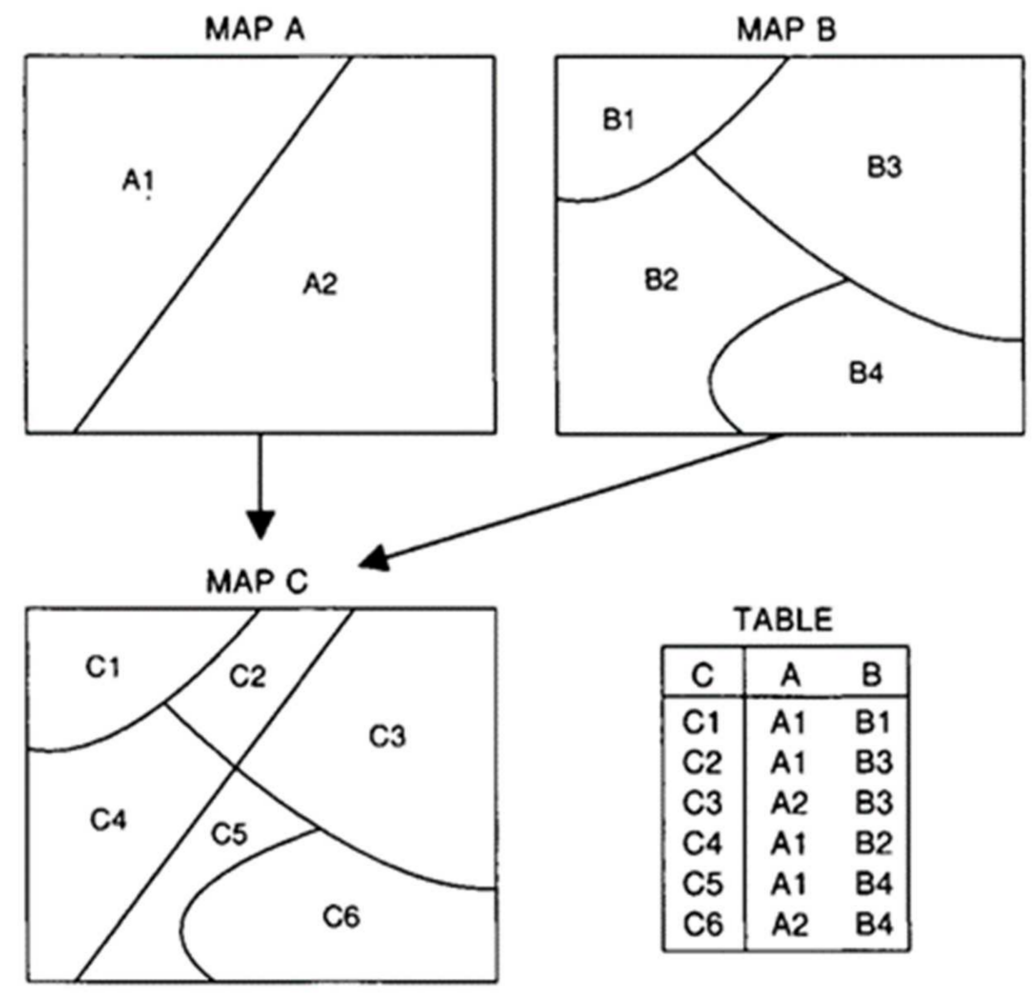

Figure 6. Overlay of two polygon maps, producing a new set of polygons common to both maps. The polygons in C are not linked to the polygons of maps A and B in a polygon attribute Table 2.

\section{Results}

The level of damage to buildings after the Lombok earthquake (Table 2), adapted from the Mataram city redevelopment action plan in 2018, shows the number of damaged houses in each district in Mataram City. The highest level of damage is in the Ampenan (AM) district, where as many as 4773 units are dominated by light (3162 units), moderate (957 units) and severe (654 units) damage; Second, the number of houses damaged in the Sekarbela district was 3774 units, consisting of 1540 units heavily damaged, moderately damaged (944 units) and lightly damaged (1290 units); Selaparang district contained 1972 damaged houses, dominated by light (1399 units), moderate (495 units), heavily (78 units) damaged; in Mataram Regency, the number of houses damaged was 1467 houses, consisting of lightly (1101 units), moderately (267 units) and heavily (99 units) damaged; Furthermore, the Sandubaya district suffered damage as many as 1211 housing units, consisting of lightly (1096 units), moderately (96 units) and heavily (19) damaged units; Finally, Cakranegara Regency suffered damage as many as 270 houses, with light (246 units), moderate (18 units) and six houses heavily damaged.

The value of losses due to house damage is calculated based on the standard value of the level of damage due to the Lombok earthquake (Table 3), where total loss (100\%) is US\$ 6320; heavily damaged (80\%) worth US\$ 5056; moderate damage (50\%) worth US\$ 3160; and Low (20\%) at $\$ 1264$. Then the value of the loss for each district (Table 4) is the highest loss suffered by Sekarbela (SK) of US\$12,399,840, the second loss of Ampenan (AM) US\$ 10,327,512, followed by Selaparang (SL) of US\$ 3,726,904; Mataram (MA) suffered a loss of US\$2,735,928; Sandubaya (SA) of US\$1,784,768 and the last is Cakranegara (CA) of US\$ 398,160. 
Table 2. Level of buildings damages after the earthquake per district in Mataram City (adapted from Mataram City redevelopment action plan, BNPB).

\begin{tabular}{cccccc}
\hline \multirow{2}{*}{ No } & \multirow{2}{*}{ District } & \multicolumn{4}{c}{ Damage Data (Units) } \\
\cline { 3 - 6 } & & Heavy & Moderate & Light & Total \\
\hline 1 & Ampenan (AM) & 654 & 957 & 3.162 & 4.773 \\
\hline 2 & Cakranegara (CA) & 6 & 18 & 246 & 270 \\
\hline 3 & Mataram (MA) & 99 & 267 & 1.101 & 1.467 \\
\hline 4 & Selaparang (SL) & 78 & 495 & 1.399 & 1.972 \\
\hline 5 & Sandubuya (SD) & 19 & 96 & 1.096 & 1.211 \\
\hline 6 & Sekarbela (SK) & 1.540 & 944 & 1.290 & 3.774 \\
\hline & Total & 2.396 & 2.777 & 8.294 & 13.467 \\
\hline
\end{tabular}

Table 3. Standard budget for house rehabilitation based on level of damage (BNPB).

\begin{tabular}{cccc}
\hline Total Loss & High & Moderate & Low \\
\hline $100 \%$ & $80 \%$ & $50 \%$ & $20 \%$ \\
\hline US\$ 6320 & US\$ 5056 & US\$ 3160 & US\$ 1264 \\
\hline
\end{tabular}

Table 4. Value of losses after the earthquake per district in Mataram City.

\begin{tabular}{cccccc}
\hline \multirow{2}{*}{ No } & \multirow{2}{*}{ District } & \multicolumn{4}{c}{ Value of Damage (US\$) } \\
\cline { 3 - 6 } & Ampenan (AM) & Heavy & Moderate & Light & Total \\
\hline 1 & Cakranegara (CA) & $30,306,624$ & $3,024,120$ & $3,996,768$ & $10,327,512$ \\
\hline 2 & Mataram (MA) & 500,544 & 56,880 & 310,944 & 398,160 \\
\hline 3 & Selaparang (SL) & 394,368 & 843,720 & $1,391,664$ & $2,735,928$ \\
\hline 4 & Sandubuya (SD) & 96,064 & $3,564,200$ & $1,768,336$ & $3,726,904$ \\
\hline 5 & Sekarbela (SK) & $7,786,260$ & $2,983,040$ & $1,385,344$ & $1,784,768$ \\
\hline 6 & Total & $12,114,176$ & $8,775,320$ & $10,483,616$ & $12,396,840$ \\
\hline
\end{tabular}

The loss rating and dominance of the red zone reflect a pattern of conformity based on the magnitude of losses caused by the earthquake (Table 5). The ranking of earthquake losses is directly related to the prevalence of the red zone distribution in the districts of Sekarbela (SK) and Ampenan (AM). It implied that areas with red zone domination post-earthquake would also suffer significant losses. Based on the rating of the loss value compared to the level of the vulnerability zone (red), it shows the suitability of the pattern. The value of losses due to the earthquake is directly proportional to the dominance of the red zone distribution in the Sekarbela and Ampenan districts. These show that postearthquake, subdistricts with high red zone dominance will also have high losses. 
Table 5. Comparative tables of regional microzonation and damage-loss data.

\begin{tabular}{|c|c|c|c|c|c|c|}
\hline \multirow{2}{*}{ District } & \multicolumn{3}{|c|}{ Rank (Damages and Losses) } & \multicolumn{3}{|c|}{ Zone (\%) (Microzonation) } \\
\hline & Population & Damage & Loss & Red & Yellow & Blue \\
\hline Sekarbela (SK) & 5 & 2 & 1 & 88.52 & 11.48 & 0 \\
\hline Ampenan (AM) & 4 & 1 & 2 & 79.81 & 20.19 & 0 \\
\hline Mataram (MA) & 3 & 4 & 4 & 67.01 & 32.99 & 0 \\
\hline Selaparang (SL) & 1 & 3 & 3 & 33.04 & 55.14 & 11.82 \\
\hline Sindubaya (SD) & 2 & 5 & 5 & 17.36 & 0 & 82.64 \\
\hline Cakranegara (CA) & 6 & 6 & 6 & 0 & 14.63 & 85.37 \\
\hline
\end{tabular}

\section{Discussion}

The research area has a thickness of soft rock (volcanic fluvial deposits) which causes earthquake waves to be trapped and amplified, explaining the higher degree of damage. The distribution of damage from the earthquake on Lombok Island was irregular. The study shows that the microzonation map helps determine the damage zone and level of disaster vulnerability due to the earthquake hazards. Earthquake hazard microzonation mapping is an essential tool for land use planning in infrastructure development and mitigation strategies. It provides easy-to-read charts and maps, making it easier for governing bodies to make decisions. It is highly recommended that microzonation studies support urban planning development, residential areas, and areas of people's economic activities in disaster-safe areas.

Microzonation studies over large areas can support urban development plans and designs. This study can mitigate potentially earthquake-prone areas by recording the physical properties of rocks in static conditions so that determining the designation of an area can be more manageable. This research is relatively inexpensive, easy, and suitable for developing and utilizing regions. The blue zone area must be designated for housing, buildings, and areas for community economic activities. While the yellow zone is suitable for developing community activities such as workshops and carpentry, locations included in the red zone allocates as a buffer area for environmental conservation that is reforested by governance programs to reduce carbon emissions.

The level of damage to areas that caused significant losses is dominant in the red zone, although the highest population is not in the areas where the loss rate is high Local governments should reform land usage and distribution following the disastrous Lombok earthquake.

Based on the comparison between the level of building damage and the value of the loss, it concluded that although the number of damaged houses in the Ampenan district is the highest (4773 units) worth US\$ $10,327,512$, the loss value is still below that of the Sekarbela district ( 3774 units), but the loss value is US $\$ 12,399,840$. The number of houses with severe damage dominates the number of damaged in Sekarbela (1540 units), while the value of losses in other districts is proportional to the level of damage. The high level of loss in Sekarbela, caused by the dominance of the number of heavily damaged houses being more than Ampenan.

Future development planning may be more successful in site selection for important infrastructure investment decisions with a scientific understanding of each earthquake hazard level [34,35]. During the 2018-2020 timeframe, 61.000 homes were built for earthquake victims, ranging from mildly damaged to badly damaged homes, while 225.000 buildings were constructed for public amenities and social functions, and millions of dollars were spent to recover the damage [36]. Risk transfer is a strategy to cope with the effects of natural disasters. Natural disasters are unforeseeable, unpredictable phenomena that can have a devastating impact on the population, wreaking havoc on infrastructure and causing enormous human and economic losses [5]. An alternative to risk transfer is disaster insurance, especially earthquake insurance. Earthquake insurance is essential to recover from earthquake disasters and protect from the associated financial losses [37,38]. 


\section{Conclusions}

Its location in the collision zone causes frequent natural disasters in Indonesia. Earthquakes are one of such disasters caused by tectonic activities. The dynamic interaction of numerous tectonic plates in eastern Indonesia causes high seismicity rates, which resulted in catastrophic damaging earthquake sequences on Lombok Island in 2018. The research area in the present study has a thickness of the soft rock (volcanic fluvial deposits), causing earthquake waves to be trapped and amplified, which explains the higher level of damage. The distribution of damage caused by the earthquake on the island of Lombok is irregular. Therefore, it can be concluded that mapping hazard zones based on microzonation are directly proportional to the damage and losses caused by the earthquake. In other words, areas included in the red zone are the most vulnerable to damage and losses. In other words, areas included in the red zone are the most vulnerable to damage and losses.

Microzonation research is a valuable tool for mapping potential earthquake threats in a particular area, making research more detailed and accurate. In addition, it is essential to conduct regional tectonic research and its influence on local geological structures that impact Tertiary bedrock covered by Quaternary volcanic rock from the eruption of Mount Rinjani. It is suggested that local government improve the "building code" rules when applying for building permits.

Based on the findings of this study, it is also suggested that additional models be investigated to predict the amount of seismic activity, such as the Markov Chain model, which has been applied to the Algerian region [39]. As a result, the seismic activity can be observed using multiple models to gain a more comprehensive understanding. Meanwhile, since this region is located in a steep area, land use for forests and farmland does not require considerable consideration due to the earthquakes. As a result, substantial consideration must be given to slope stability, building structures, and available types of settlement materials [40].

Author Contributions: B.S. performed manuscript writing, sampling, measurements, data analysis, and summarized conclusions of this research. D.M. supervised writing, organizing structure of the manuscript, and morphotectonic and neotectonic data analysis. M.S.S. performed data sampling and acquisition. G.O.M. (B.Sc., junior researcher, geomorphologist) performed data measurement. S.B. supervised data analysis. H.H. supervised data analysis. All authors have read and agreed to the published version of the manuscript.

Funding: This research received no external funding.

Institutional Review Board Statement: Not applicable.

Informed Consent Statement: Not applicable.

Data Availability Statement: The original data come from Authors and references from Geological Agency and BNPB.

Acknowledgments: The authors would like to express their gratitude to the Coordinating Ministry of Maritime and Investment and the Ministry of Finance of Indonesia for their support in this research.

Conflicts of Interest: This research is purely performed to complete doctoral studies. The author declares no conflict of interest.

\section{References}

1. Lüschen, E.; Müller, C.; Kopp, H.; Engels, M.; Lutz, R.; Planert, L.; Shulgin, A.; Djajadihardja, Y.S. Structure, evolution and tectonic activity of the eastern Sunda forearc, Indonesia, from marine seismic investigations. Tectonophysics 2011, 508, 6-21. [CrossRef]

2. Ramdani, F.; Setiani, P.; Setiawati, D.A. Analysis of sequence earthquakes of Lombok Island, Indonesia. Prog. Disaster Sci. 2019, 4, 100046. [CrossRef]

3. Supendi, P.; Nugraha, A.D.; Widiyantoro, S.; Pesicek, J.D.; Thurber, C.H.; Abdullah, C.I.; Daryono, D.; Wiyono, S.H.; Shiddiqi, H.A.; Rosalia, S. Relocated aftershocks and background seismicity in eastern Indonesia shed light on the 2018 Lombok and Palu earthquake sequences. Geophys. J. Int. 2020, 221, 1845-1855. [CrossRef]

4. BNPB. Action Plan for Post-Earthquake Rehabilitation and Reconstruction in 2018-2019; National Disaster Management Agency (BNPB): New Delhi, India, 2018. 
5. Hidalgo, J.; Baez, A.A. Natural Disasters. Crit. Care Clin. 2019, 35, 591-607. [CrossRef] [PubMed]

6. Hidayat, E.; Muslim, D.; Zakaria, Z.; Permana, H.; Wibowo, D.A. Tectonic geomorphology of the Karangsambung area, central Java, Indonesia. Rud. Geol. Naft. Zb. 2021, 36, 85-105. [CrossRef]

7. Koulali, A.; Susilo, S.; McClusky, S.; Meilano, I.; Cummins, P.; Tregoning, P.; Lister, G.; Efendi, J.; Syafi'I, M.A. Crustal strain partitioning and the associated earthquake hazard in the eastern Sunda-Banda Arc. Geophys. Res. Lett. 2016, 43, 1943-1949. [CrossRef]

8. DeMets, C.; Calais, E.; Merkouriev, S. Reconciling geodetic and geological estimates of recent plate motion across the Southwest Indian Ridge. Geophys. J. Int. 2017, 208, 118-133. [CrossRef]

9. Sarris, C.; Loupasakis, P.; Soupios, V.; Trigkas, F. Vallianatos, Earthquake vulnerability and seismic risk assessment of urban areas in high seismic regions: Application to Chania City, Crete Island, Greece. Nat. Hazards 2010, 54, 395-412. [CrossRef]

10. Geological Agency. Microzonation Potential Earthquake Hazard Assessment Map of Mataram City, West Nusa Tenggara Province; Geological Agency Ministry of Energy and Mineral Resources: Bandung, Indonesia, 2015.

11. USGS. Available online: https:/ / earthquake.usgs.gov/ earthquakes/map (accessed on 5 January 2022).

12. Kanai, K.; Tanaka, T.; Osada, K. Measurement of the Micro-tremor 1. Bull. Earthq. Res. Inst. Univ. Tokyo 1954, 32, $199-209$.

13. Nakamura, Y. Clear identification of fundamental idea of Nakamura's technique and its applications. In Proceedings of the XII World Conference Earthquake Engineerin, Auckland, New Zealand, 30 January-4 February 2000. Paper no 2656.

14. Khalili, M.; Mirzakurdeh, A.V. Fault detection using microtremor data (HVSR-based approach) and electrical resistivity survey. J. Rock Mech. Geotech. Eng. 2019, 11, 400-408. [CrossRef]

15. Soehaimi, A.; Muslim, D.; Kamawan, I.; Negara, R.S. Microzonation of the Liwa city on the great sumatera active fault and giant ranau volcanic complex in south sumatera, Indonesia. In Engineering Geology for Society and Territory; Springer: Cham, Switzerland, 2015; Volume 5. [CrossRef]

16. Molnar, S.; Cassidy, J.F.; Castellaro, S.; Cornou, C.; Crow, H.; Hunter, J.A.; Matsushima, S.; Sánchez-Sesma, F.J.; Yong, A. Application of Microtremor Horizontal-to-Vertical Spectral Ratio (MHVSR) Analysis for Site Characterization: State of the Art. Surv. Geophys. 2018, 39, 613-631. [CrossRef]

17. Syahbana, A.J.; Iqbal, P.; Irsyam, M.; Asrurifak, M.; Hendriyawan, H. Smoothed gridded seismicity effect for land-use development, case study: Kalimantan Island, Indonesia. Rud. Geol. Naft. Zb. 2021, 36, 115. [CrossRef]

18. Idriss, I.M.; Boulanger, R.W. Soil Liquefaction During Earthquakes; EERI Publication, Monograph MNO-12; Earthquake Engineering Research Institute: Oakland, New Zeland, 2008.

19. Ibs-von Seht, M.; Wohlenberg, J. Seismic noise spectra used to map thickness of soft sediments. In Proceedings of the 58th EAEG Meeting, Amsterdam, The Netherlands, 7 June 1996. [CrossRef]

20. Seht, M.I.V.; Wohlenberg, J. Microtremor Measurements Used to Map Thickness of Soft Sediments. Bull. Seismol. Soc. Am. 1999, 89, 250-259. [CrossRef]

21. Tuladhar, R.; Yamazaki, F.; Warnitchai, P.; Saita, J. Seismic microzonation of the greater Bangkok area using microtremor observations. Earthq. Eng. Struct. Dyn. 2004, 33, 211-225. [CrossRef]

22. Yulianur, A.; Saidi, T.; Setiawan, B.; Sugianto, S.; Rusdi, M.; Affan, M. Microtremor datasets at liquefaction site of Petobo, Central Sulawesi-Indonesia. Data Brief 2020, 30, 105554. [CrossRef]

23. Mangga, S.; Atmawinata, S.; Hermanto, B.; Setyogroho, B.; Amin, T.C. Geological Map of The Lombok Sheet, West Nusa Tenggara; Geological Research and Development Centre: Bandung, Indonesia, 1994.

24. Sugiyanto, P.T.; Wafid, M. Engineering Geological Map of The Lombok Island, West Nusa Tenggara; Geological Agency: Bandung, Indonesia, 2014.

25. Jena, R.; Pradhan, B.; Beydoun, G. Earthquake vulnerability assessment in Northern Sumatra province by using a multi-criteria decision-making model. Int. J. Disaster Risk Reduct. 2020, 46, 101518. [CrossRef]

26. Bonham-Carter, G. Geographic information systems for geoscientists: Modelling with GIS. Comput. Methods Geosci. 2014, 13, 398.

27. Janssen, R.; Rietveld, P. Multicriteria Analysis and Geographical Information Systems: An Application to Agricultural Land Use in the Netherlands; Geographical Information Systems for Urban and Regional Planning, Kluwer: Dordrecht, Netherlands, 1990. [CrossRef]

28. Keller, C.P. Geographic information systems for geoscientists: Modelling with GIS. Comput. Geosci. 1995, 21. [CrossRef]

29. Malczewski, J. GIS-based land-use suitability analysis: A critical overview. Prog. Plan. 2004, 62, 3-65. [CrossRef]

30. Pereira, J.M.C.; Duckstein, L. A multiple criteria decision-making approach to gis-based land suitability evaluation. Int. J. Geogr. Inf. Syst. 1993, 7, 407-424. [CrossRef]

31. Yenigun, K.; Ecer, R. Overlay mapping trend analysis technique and its application in Euphrates Basin, Turkey. Meteorol. Appl. 2013, 20, 427-438. [CrossRef]

32. Yesilnacar, M.I.; Cetin, H. An environmental geomorphologic approach to site selection for hazardous wastes. Environ. Geol. 2008, 55, 1659-1671. [CrossRef]

33. Thomas, C.F. An Introduction to Geographic Information Systems. In Libraries; CRC Press: London, UK, 2019. [CrossRef]

34. Sekac, T.; Jana, S.K.; Pal, I.; Pal, D.K. GIS Based Evaluation in Earthquake Hazard Microzonation-A Case Study of Madang and Morobe Province, Papua New Guinea. Int. J. Adv. Eng. Res. Sci. 2016, 3, 236817. [CrossRef]

35. Skoufias, E. Economic crises and natural disasters: Coping strategies and policy implications. World Dev. 2003, 31, 1087-1102. [CrossRef] 
36. Mardialina, M.; Munir, A.M. Disaster Recovery in Social Aspect: Evidence from Lombok Earthquake 2018. In Proceedings of the 6th International Conference on Education \& Social Sciences (ICESS 2021), Java, Indonesia, 31 July 2021. [CrossRef]

37. Goda, K.; Wilhelm, K.; Ren, J. Relationships between earthquake insurance take-up rates and seismic risk indicators for Canadian households. Int. J. Disaster Risk Reduct. 2020, 50, 101754. [CrossRef]

38. King, A.; Middleton, D.; Brown, C.; Johnston, D.; Johal, S. Insurance: Its role in recovery from the 2010-2011 Canterbury Earthquake sequence. Earthq. Spectra 2014, 30, 475-491. [CrossRef]

39. Dahmoune, B.; Mansour, H. Algerian northwestern seismic hazard evaluation based on the markov model. Rud. Geol. Naft. Zb. 2019, 34, 113-125. [CrossRef]

40. Munirwansyah; Irsyam, M.; Munirwan, R.P.; Yunita, H.; Zulfan, U.M. Geotechnical approach for occupational safety risk analysis of critical slope in open pit mining as implication for earthquake hazard. IOP Conf. Ser. Mater. Sci. Eng. 2018, $352,012035$. [CrossRef] 